\title{
Review of Control Techniques in Distributed Power Generation Systems
}

\author{
Revisión Sobre Técnicas de Control en Sistemas de Generación Distribuida de Energía
}

\author{
Helbert Eduardo Espitia (1) 1* | Iván Machón-González ${ }^{(1)} 2^{*}$ | \\ Hilario López-García (1D 2*
}

${ }^{1}$ Facultad de Ingeniería, Universidad Distrital Francisco José de Caldas, Bogotá, Colombia

${ }^{2}$ Departamento de Ingeniería Eléctrica, Electrónica de Computadores y Sistemas, Universidad de Oviedo, Campus de Viesques, Gijón/Xixón, Spain

\section{Correspondence}

Helbert Eduardo Espitia, Universidad

Distrital, Bogotá, Colombia

Email: heespitiac@udistrital.edu.co

Copyright : Licencia de Creative Commons Reconocimiento-NoComercial 4.0 Interna.

\section{@creative}

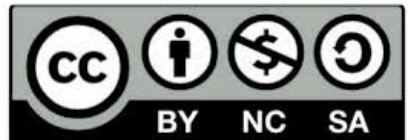

Editors: Robert Paul Salazar, Germán Chaparro, Luz Adriana Suárez.

ABSTRACT. In this document are revised different control techniques applied to distributed generation systems, including control of active-reactive power, load-frequency control and the identification and control of island mode operation of the generation units, which are the main themes identified. The different control strategies identified are PID, robust, predictive and fuzzy, with applications in the aforementioned subjects. Particularly, applications for the interconnection of generation units and the control of the electric power conversion system DC-AC (inverter) are observed.

keywords: Control, Distributed Generation, Power, Review.

RESUMEN. En este documento se realiza la revisión sobre diferentes técnicas de control aplicadas a sistemas de generación distribuida. Sobre las principales temáticas identificadas se tiene el control de potencia activareactiva, el control de carga-frecuencia y la identificación y control del funcionamiento en modo de isla de las unidades de generación. Sobre las diferentes estrategias de control identificadas se tiene: PID, robusto, predictivo y difuso, con aplicaciones en los temas antes citados. Particularmente se aprecian aplicaciones para la interconexión de unidades de generación y el control del sistema de conversión de energía eléctrica DC-AC (inversor).

Palabras clave: Control, Energía, Revisión, Generación Distribuida.

How to cite

Espitia H., Machón I. and López H., Review of Control Techniques in Distributed Power Generation Systems, TECCIENCIA, Vol. 14, No. 27, 11-22, 2019

DOI:http://dx.doi.org/10.18180/tecciencia.2019.27.2

\section{1 | INTRODUCTION}

1 Currently, electric energy demands are arising worldwide, whence power plants and transmission lines must

2 be designed attending the demands of consumers. In this regard, the Distributed Generation (DG) costs are

3 lower than those for a power plant and the expansion of the system distribution and transmission. Adequate

*Equally contributing authors. 
strategies to interconnect the microgrids are mandatory to both to satisfy the increment of charge power as well as the reliability of energy supply.

Likewise, DG systems using a renewable source of energy show an accelerated development. Under this approach, hybrid systems can be used to combine more energy sources; despite the advantages provided by the DG, problems like oscillations in the system frequency, breaches in the energy capacity of the lines, and the increase of voltage may arise. In this regard, there are several strategies for voltage control, particularly, methods of reactive power control which have demonstrated to achieve voltage production inside permissible ranges without reducing the active power.

This paper focuses in the review of the different control strategies for DG systems. Some review studies related to Distributed Generation systems are observed in [1, 2, 3, 4, 5, 6].

Concerning the review of energy conversion systems using inverters, a recounting of the parallel operation of inverters and power filters of active power in Distributed Systems is made in [1]; besides, [2] reviews the topologies and control strategies of inverters connected to multi-functional networks to improve the power quality.

Meanwhile, [3] makes a review of the literature about load-frequency control to conventional and distributed generation systems. The objective of the Load-Frequency Control (LFC) in an interconnected system consists of keeping the frequency in each area into the boundaries and keep the power flow inside some predetermined tolerances through the adjustments in the outputs of the generators.

Another referential paper is [4] where power generation based on an integrated system of renewable energy takes place particularly observing the configurations, storage options, size and control systems.

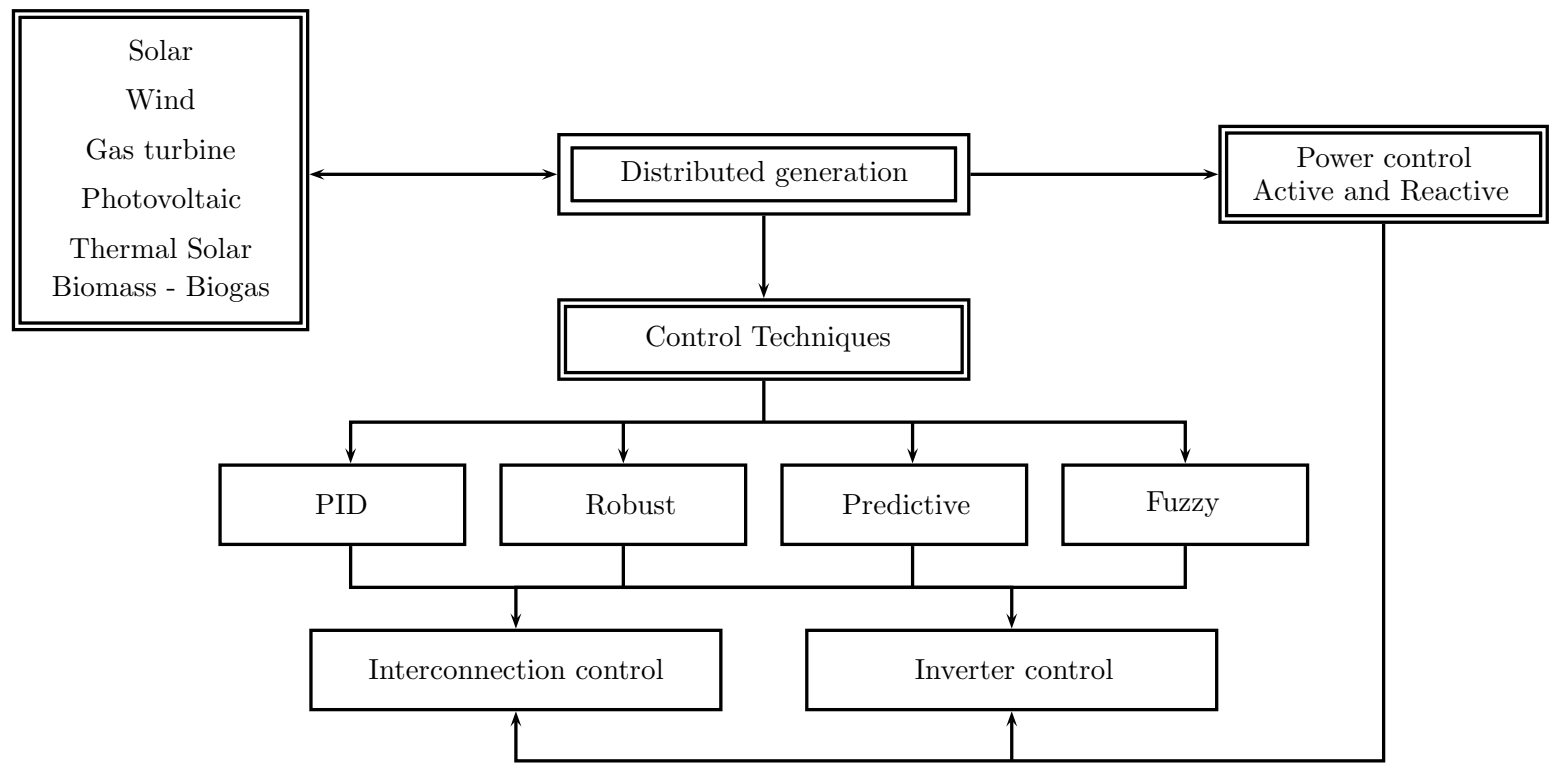

FIG. 1 Main characteristics identified.

Besides, [5], [6], and [7] is made a recount on the about the control of distributing electric energy systems for applications in microgrids. In [8] can be seen a review of the computational intelligence techniques employed to detect the isle mode functioning of units of distributed generation.

Another aspect considered for distributed generation systems include the methods to locate generators; in this regard, [9] reviews the problem of assigning of DG from the employed algorithm optimization perspective, the objectives, variables decision, DG type, applied restrictions, and the type of uncertainty modeling used.

Together with these review articles, it can be found others with different orientations of applied systems of control used in distributed generation. The first group of works focuses on different strategies employed for control of active and reactive power. From a control techniques perspective, PID-type, predictive, robust, and 
fuzzy approaches are the most visible. These works display different strategies and applications of control systems highlighting two approaches: one that is focused in the conversion control system loop of electric energy DC-AC (the inverter). The other approach is focused in the control system for the interconnection of the different units of generation of the distributed system. Fig. 1 shows the mentioned relation of control systems applied to the distributed generation ones.

\section{2 | GENERAL APPROACHES ABOUT CONTROL IN DISTRIBUTED GENERATION SYSTEMS}

In general, the approaches in distributed generation control systems are the active and reactive power control, the interconnection of units of generation, island detection and remarkably, the control of the proper loops of the DC-AC inverter.

The distributed generation units interconnect with the electric supply network through three-phase inverter whereby the applications for controlling the active and reactive power are focused on the strategies to control the inverter. Some works where some strategies for controlling the flow of power can be seen in $[10,11,12,13,14]$. Meanwhile, $[15,16,17,18,19]$ are works focused on reactive power control.

Another key aspect in distributed generation systems is the interconnection of the different units of generation where it is aimed the reduction of distortion effects of voltage signals to obtain a stable system; $[20,21,22,23]$ are related works. A particularly interesting aspect is the interconnection of hybrid systems, that is, generation units of different nature. These works also focus on energy dispatch, for which techniques of prediction are implemented (forecast) to determine the power necessary to supply in specific moments.

Reference [24] displays a focus to coordinate the injection of power of the distributed generators by offering a method for voltage control of a distribution network based on the voltage sensitivity matrix. This matrix is employed to coordinate the complex power injection of the distributed generators, which is determined by observing the effect that each generator has on the nodes in the distribution network.

Operation in Islanding mode is the situation by which a distribution system is electrically isolated from the rest of the generation system and yet it keeps power over a some time. Applications focused on detection and control of the phenomenon are seen in [25, 26, 27].

Finally, several works with the development of strategies can be seen being the inverter the element by which the connection and the energy conversion are made. Such developments aim towards the regulation of electricity, the voltage, and the power supply. Some works on inverter control system can be seen in $[28,29,30,31,32]$.

\section{3 | PID CONTROL}

Regarding PID (Proportional, Integral, and Derivative) control applications there exist the control of different generation units, control of the in the interconnection of the generation units, and the control of the proper loops of the inverter.

On the particular control of some generation power plants there exist hydraulic turbines [33], thermal systems [34], wind turbines [35], and photovoltaic systems [36], among others.

In relation with the control of the interconnection of the distributed generation systems, it is observable the works developed in $[37,38,39,40,41]$ where optimization algorithms are also employed to adjust the control parameters.

Regarding the inverter, in [42] is shown the design of a resounding controller, while in [43] is shown an interface design to integrate the solar photovoltaic generation systems.

Finally, [44] introduces an improved scheme of the Voltage Oriented Control (VOC) to control an inverter connected to a triphasic network. The inverter is considered the central part of the System of Distributed Generation. An optimization method is employed to recursively adjust the controller parameters PID aiming to achieve an ideal performance of the DG unit connected to the network. 


\section{4 | ROBUST CONTROL}

In relation to applications of robust control in systems of distributed generation were mainly identified the interconnection of the control units and the control of the element of conversion of energy (inverter).

Some applications of robust control for interconnection of generation units are observed in [45] for voltage control, in [46, 47, 48] for frequency control and in [49] for conditions of unbalance. Particularly, designs based on $H_{\infty}$ are presented in [50,51, 52].

About robust control applications emphasized on the loops of the inverter control, in [53] a robust predictive scheme is presented with intrinsic synchronism for the direct power control. Meanwhile, [54] shows a design of robust control for distributed generation in microgrids using direct control of voltage. In [55] the Lyapunov method is applied for the stable functioning of distributed generation based on a multilevel converter. Moreover, [56] displays the design of a regulator in sliding mode to supply the maximum power. Finally, [57] presents a hybrid robust control for an inverter DC-AC of one single phase with variations in the input voltage.

\section{5 | PREDICTIVE CONTROL}

About this technique, in [58] design of a predictive control system for a four-arms inverter is presented. Another application [59] consists of the dispatch of energy which is made for the predictive control for the distributed generation.

Another observed application for the predictive control technique consists of the interconnection among the units of distributed generation; in this regard, [60] compares the centralized and distributed predictive control schemes for the regulation of damped electromagnetic oscillations. In addition, [61] and [62] propose predictive control systems for Load Frequency Control (LFC). Those systems aim that after a change of load in each area the frequency error is suppressed in a permanent regimen; moreover, each area must also keep the power flow programmed. Meanwhile [63] shows a study about energy management in local microgrids based on predictive control strategies. On the other hand, [64] presents the design of a stochastic predictive control for energy dispatch in an eolian park. Another work to consider is in [65] where the Economic Dispatch (ED) is incorporated for the operation of a microgrid proposing a methodology of predictive control. The control system is completely distributed, and each distributed generation system is able to communicate with other nodes for the iterative calculation of the optimization process. A microgrid with different sources of energy is simulated to determine the performance compared with a strategy of centralized control.

\section{6 | FUZZY CONTROL}

There are different applications for this technique, which include:

- PID fuzzy control

- Disturbance detection

- Detection in Island mode operation

- Energy dispatch

- Interconnection of distributed generation systems

- Control of the inverter

\section{1 | PID Fuzzy control}

These applications combine the strategy of conventional control PID with the scheme of approximate reasoning of the fuzzy systems. Particularly, [66] and [67] show the design of PID control systems with gain scheduling. Through the information provided to the fuzzy system the PID controller parameters adjustment is made. Similar work is observed in [68] where a supervised scheme is proposed based on a fuzzy system to 
adjust the parameters in a PID controller.

Another application that includes a PID adaptive controller is shown in [69], where the loop of the inverter control is detailed presented for the power control and synchronism with the network. Meanwhile, in [70] takes place the optimization of PID fuzzy controller using the differential evolution algorithm.

\section{2 | Disturbances detection}

In relation disturbances detection [71] studies this type of applications for disturbance detection in eolian parks using a neuro-fuzzy system. Moreover, [72] proposes a neuro-fuzzy methodology to determine the load margin when having intermittency in the sources.

\section{3 | Island mode functioning detection}

An approach to the problem of detection in island mode in distributed generation using fuzzy logic can be seen in [73], while [74] develops a fuzzy logic system with a time-frequency hybrid focus for sources of distributed generation. Finally, in [75] a scheme is proposed for island mode detection using Wavelet filtered and a neurofuzzy system.

\section{4 | Energy dispatch}

About energy dispatch [76] and [77] show an application for dispatching energy employing fuzzy logic. Here, a sequential quadratic programming algorithm is used to obtain an optimal solution for energy distribution among multiple units of distributed generation. Later, a fuzzy system is implemented to put into practice the optimal strategies previously found. In addition, the parameters of the fuzzy system were adapted by a genetic algorithm; meanwhile, in [78] ca be seen a strategy employed for the prediction of time series to regulate the dispatch of energy.

\section{5 | Interconnection of distributed generation systems}

On works focused on the interconnection of units of distributed generation, in [79] design of a fuzzy system is made for the load frequency control for a multi-area generation system.

Furthermore, in [80], [81], and [82] present a study for the interconnection of units of generation of different nature like fuel cells and bank of batteries. Other strategies of fuzzy control for the interconnection of hybrid systems can be seen in [83] and [84]. The implementation of evolutive algorithms for optimizing the control systems is a particular remark of these works.

In addition, [85] presents the robust fuzzy controller design for an isolated generator connected to an infinite barrage to foretell changes present in the load.

Finally, [86] presents a control system for the interconnection of distributed generation resources to electrical networks by power electronic converters. It is proposed a fuzzy adaptive control system based on the theory of stability of Lyapunov for the converter power loop. With the proposed scheme of control is aimed at an adequate follow-up the current of reference to provide a suitable dynamic response.

\subsection{Control of the inverter}

Concerning the control strategies focused in the inverter control loops in [87] and [88] can be seen the application of neuro-fuzzy systems in different parts of the system of energy conversion.

Regarding other applications, in [89] is presented the design of a fuzzy controller for a micro-turbine in a distributed generation system. In [90] is observed an application for controlling a fuel cell; in this work is performed the regulation of voltage. Finally, [91] presents the design of a fuzzy controller for an induction generator with a double set of stator coils. 


\subsection{Discussion}

Different approaches can be identified for the control on systems of distributed generation with this revision which, in the first place, obey the variable to control and, in second place, they also obey the focus of the control system. It is remarkable the application of techniques of computational intelligence with neural networks and fuzzy logic as the system of distributed generation presents a degree of complexity where the techniques of soft computing can be a good alternative to implement.

\section{7 | CONCLUSIONS}

Through this review were visible the most relevant characteristics of the control techniques in distributed generation systems.

As seen through the review the fuzzy control technique presents a higher number of applications, which shows its flexibility to be implemented in different applications of distributed generation.

This review also allows observing the possibility to create new control techniques applied to distributed generation. An alternative consists of a non-linear control technique based on fuzzy sets which can be a type-supervised identifying the power plant to perform the control.

\section{References}

[1] K. Khadem, M. Basu, M.F. Conlon, Parallel operation of inverters and active power filters in distributed generation, Renewable and Sustainable Energy Reviews, vol. 15, 2011, p. 5155-5168.

[2] Zheng Zeng, Huan Yang, Rongxiang Zhao, Chong Cheng, Topologies and control strategies of multi-functional grid-connected inverters for power quality enhancement: A comprehensive review, Renewable and Sustainable Energy Reviews, vol. 24, 2013, p. 223-270.

[3] Shashi Kant Pandey, Soumya R. Mohanty, Nand Kishor, A literature survey on load-frequency control for conventional and distribution generation power systems, Renewable and Sustainable Energy Reviews, vol. 25, 2013, p. 318-334.

[4] Anurag Chauhan, R.P. Saini, A review on Integrated Renewable Energy System based power generation for stand-alone applications: Configurations, storage options, sizing methodologies and control, Renewable and Sustainable Energy Reviews, vol 38, 2014, p. 99-120.

[5] Allal M. Bouzid, Josep M. Guerrero, Ahmed Cheriti, Mohamed Bouhamida, Pierre Sicard, Mustapha Benghanem, A survey on control of electric power distributed generation systems for microgrid applications, Renewable and Sustainable Energy Reviews, vol. 44, 2015, p. 751-766.

[6] Omid Palizban, Kimmo Kauhaniemi, Hierarchical control structure in microgrids with distributed generation: Island and grid-connected mode, Renewable and Sustainable Energy Reviews, vol 44, 2015, p. 797-813.

[7] Nasif Mahmud, A. Zahedi, Review of control strategies for voltage regulation of the smart distribution network with high penetration of renewable distributed generation, Renewable and Sustainable Energy Reviews, vol. 64, 2016, p. 582-595.

[8] J.A. Laghari, H. Mokhlis, M. Karimi, A.H.A. Bakar, Hasmaini Mohamad, Computational Intelligence based techniques for islanding detection of distributed generation in distribution network: A review, Energy Conversion and Management, vol. 88, 2014, p. 139-152.

[9] Ahmad Rezaee Jordehi, Allocation of distributed generation units in electric power systems: A review, Renewable and Sustainable Energy Reviews, vol. 56, 2016, p. 893-905. 
[10] Min Dai, Mohammad N. Marwali, Jin-Woo Jung, Ali Keyhani, Power Flow Control of a Single Distributed Generation Unit with Nonlinear Local Load, IEEE PES Power Systems Conference and Exposition, 2004, p. 398-403.

[11] Min Dai, Mohammad Nanda Marwali, Jin-Woo Jung, Ali Keyhani, Power Flow Control of a Single Distributed Generation Unit, IEEE Transactions on Power Electronics, vol. 23, no. 1, 2008, p. 343-352.

[12] Yong Xue, Jiamei Deng, Shuangbao Ma, Power Flow Control of a Distributed Generation Unit in Micro-grid, IEEE 6th International Power Electronics and Motion Control Conference (IPEMC), 2009, p. 2122-2125.

[13] Yun Wei Li, Ching-Nan Kao, An Accurate Power Control Strategy for Power-Electronics-Interfaced Distributed Generation Units Operating in a Low-Voltage Multibus Microgrid, IEEE Transactions on Power Electronics, vol. 24, no. 12, 2009, p. 2977-2988.

[14] R. Bojoi, L. R. Limongi, D. Roiu A. Tenconi, Enhanced Power Quality Control Strategy for Single-Phase Inverters in Distributed Generation Systems, IEEE Transactions on Power Electronics, vol. 26, no. 3, 2011, p. 798-806.

[15] M. Prodanovic, K. De Brabandere, J. Van den Keybus, T. Green, J. Driesen, Harmonic and reactive power compensation as ancillary services in inverter-based distributed generation, Generation, Transmission \& Distribution (IET), vol. 1, no. 3, 2007, p. 432-438.

[16] Pedro M. S. Carvalho, Pedro F. Correia, Luís A. F. M. Ferreira, Distributed Reactive Power Generation Control for Voltage Rise Mitigation in Distribution Networks, IEEE Transactions on Power Systems, vol. 23, no. 2, 2008, p. 766-772.

[17] Ferry A. Viawan, Daniel Karlsson, Coordinated Voltage and Reactive Power Control in the Presence of Distributed Generation, IEEE Power and Energy Society General Meeting - Conversion and Delivery of Electrical Energy in the 21st Century, 2008, p. 1-6.

[18] Fei Wang, Jorge L. Duarte, Marcel A. M. Hendrix, Active and Reactive Power Control Schemes for Distributed eneration Systems Under Voltage Dips, IEEE Energy Conversion Congress and Exposition (ECCE), 2009, p. 35643571.

[19] Gao Yang, Liu Li, Xu Ao-ran, Zhao Yi, Sun wen-yao, Wng Gang, Research on the Reactive Power Control of Distributed Generation System, China International Conference on Electricity Distribution (CICED), 2012, p. 1-5.

[20] M.G. Molina, P.E. Mercado, Stabilization and control of tie-line power flow of microgrid including wind generation by distributed energy storage, International Journal of Hydrogen Energy, vol 35, no. 11, 2010, p. 58275833.

[21] Maria Stefania Carmelia, Francesco Castelli-Dezza, Marco Mauri, Gabriele Marchegiani, Daniele Rosati, Control strategies and configurations of hybrid distributed generation systems, Renewable Energy, vol. 41, 2012, $p$. 294-305.

[22] X. Jin, J. Zhao, H.F. Wang, On-Line Stability Control of Power Systems Integrated with Distributed Generation Systems, Proceedings of the 41st International Universities Power Engineering Conference (UPEC), 2006, $p$. 472-476.

[23] E. Ortjohann, W. Sinsukthavorn, A. Mohd, M. Lingemann, N. Hamsic, A. Schmelter, D. Morton, Control Methodology of Distributed Generation in Interconnected Grids, IEEE/PES Power Systems Conference and Exposition (PSCE), 2009, p. 1-6.

[24] Qiong Tao, Deshun Wang, Bo Yang, Huan Liu, Shengchi Yan, Voltage Control of Distribution Network with distributed generation based on Voltage Sensitivity Matrix, IEEE International Conference on Energy Internet, 2018, p. 298-302. 
[25] Irvin J. Balaguer, Qin Lei, Shuitao Yang, Uthane Supatti, Fang Zheng Peng, Control for Grid-Connected and Intentional Islanding Operations of Distributed Power Generation, IEEE Transactions on Industrial Electronics, vol. 58, no. 1, 2011, p. 147-157.

[26] Hua Geng, Dewei (David) Xu, Bin Wu, Geng Yang, Active Islanding Detection for Inverter-Based Distributed Generation Systems With Power Control Interface, IEEE Transactions on Energy Conversion, vol. 26, no. 4, 2011, p. 1063-1072.

[27] Xiaolong Chen, Yongli Li, An Islanding Detection Algorithm for Inverter-Based Distributed Generation Based on Reactive Power Control, IEEE Transactions On Power Electronics, vol. 29, no. 9, 2014, p. 4672-4683.

[28] Majid Mehrasa, Edris Pouresmaeil, Hasan Mehrjerdi, Bo Nørregaard Jørgensenb, João P.S. Catalão, Control technique for enhancing the stable operation of distributed generation units within a microgrid, Energy Conversion and Management, vol. 97, 2015, p. 362-373.

[29] Maurizio Cirrincione, Marcello Pucci, Gianpaolo Vitale, Direct power control of three-phase VSIs for the minimization of common-mode emissions in distributed generation systems, Electric Power Systems Research, vol. 81, 2011, p. 830-839.

[30] Y. Pei, G. Jiang, X. Yang, and Z. Wang, "Auto-master-slave control technique of parallel inverters in distributed ac power systems and ups," in IEEE 35th Annual Power Electronics Specialists Conference (PESC), vol. 3, p. 2050-2053, 2004.

[31] M. Prodanović and T. C. Green, "High-quality power generation through distributed control of a power park microgrid," IEEE Transactions on Industrial Electronics, vol. 53, no. 5, p. 1471-1482, 2006.

[32] A. Timbus, M. Liserre, R. Teodorescu, and P. Rodriguez, "Frede blaabjerg, evaluation of current controllers for distributed power generation systems," IEEE Transactions on Power Electronics, vol. 24, no. 3, p. 654-664, 2009.

[33] P. Hušek, "Pid controller design for hydraulic turbine based on sensitivity margin specifications," Electrical Power and Energy Systems, vol. 55, p. 460-466, 2014.

[34] G. Liang, W. Li, and Z. Li, "Control of superheated steam temperature in large-capacity generation units based on active disturbance rejection method and distributed control system," Control Engineering Practice, vol. 21, no. 3, p. 268-285, 2013.

[35] B. Malinga, J. E. Sneckenberger, and A. Feliachi, "Modeling and control of a wind turbine as a distributed resource," in Proceedings of the 35th Southeastern Symposium on System Theory, p. 108-112, 2003.

[36] P. Li, L. Zhang, V. Wang, and Y.-B. Sheng, "Research on the control of the single-stage photovoltaic system in microgrid," in China International Conference on Electricity Distribution (CICED, p. 1-7, 2008.

[37] P. Dash, L. C. Saikia, and N. Sinha, "Automatic generation control of multi area thermal system using bat algorithm optimized pd-pid cascade controller," Electrical Power and Energy Systems, vol. 68, p. 364-372, 2015.

[38] S. Sondhi and Y. V. Hote, "Fractional order pid controller for load frequency control," Energy Conversion and Management, vol. 85, p. 343-353, 2014.

[39] K. Ashok Mohan Jadhav, "Performance verification of pid controller in an interconnected power system using particle swarm optimization," in Energy Procedia, 2nd International Conference on Advances in Energy Engineering (ICAEE), vol. 14, p. 2075-2080, 2012.

[40] G. Mallesham, S. Mishra, and A. Jha, "Maiden application of ziegler-nichols method to agc of distributed generation system," in IEEE/PES Power Systems Conference and Exposition, p. 1-7, 2009. 
[41] X. Li, X. Jiao, and L. Wang, "Coordinated power control of wind-pv-fuel cell for hybrid distributed generation systems," in Proceedings of SICE Annual Conference (SICE), p. 150-155, 2013.

[42] C. S. Thelukuntla and M. Veerachary, "Resonant controller based single-phase z-source inverter with Iclfilter," in Joint International Conference on Power Electronics, Drives and Energy Systems (PEDES), p. 1-6, 2010.

[43] E. d. S. J. J.M. Pacas, M.G. Molina, "Design of a robust and efficient power electronic interface for the grid integration of solar photovoltaic generation systems," International Journal of hydrogen energy, vol. 37, p. 10076-10082, 2012.

[44] S. Sinan and A. Elnady, "Optimized pid controller based voltage oriented control of the 7-level diode clamped inverter for distributed generation system," in International Conference on Electrical and Computing Technologies and Applications (ICECTA), p. 1-5, 2017.

[45] F. Habibi, A. H. Naghshbandy, and H. Bevrani, "Robust voltage controller design for an isolated microgrid using kharitonov's theorem and d-stability concept," Electrical Power and Energy Systems, vol. 44, p. 656-665, 2013.

[46] M. Shiroei, M. R. Toulabi, and A. M. Ranjbar, "Robust multivariable predictive based load frequency control considering generation rate constraint," Electrical Power and Energy Systems, vol. 46, p. 405-413, 2013.

[47] S. K. Pandey, S. R. Mohanty, N. Kishor, and J. P. Catalão, "Frequency regulation in hybrid power systems using particle swarm optimization and linear matrix inequalities based robust controller design," Electrical Power and Energy Systems, vol. 63, p. 887-900, 2014.

[48] Y. Han, P. M. Young, A. Jain, and D. Zimmerle, "Robust control for microgrid frequency deviation reduction with attached storage system," IEEE Transactions on Smart Grid, vol. 6, no. 2, p. 557-565, 2015.

[49] M. M. Rezaei and J. Soltani, "A robust control strategy for a grid-connected multi-bus microgrid under unbalanced load conditions," Electrical Power and Energy Systems, vol. 71, p. 68-76, 2015.

[50] V. P. Singh, S. R. Mohanty, N. Kishor, and P. K. Ray, "Robust h-infinity load frequency control in hybrid distributed generation system," Electrical Power and Energy Systems, vol. 46, p. 294-305, 2013.

[51] S. R. Mohanty, N. Kishor, and P. K. Ray, "Robust h-infinite loop shaping controller based on hybrid pso and harmonic search for frequency regulation in hybrid distributed generation system," Electrical Power and Energy Systems, vol. 60, p. 302-316, 2014.

[52] Z. Wu, F. Yan, and Q.-L. Hang, "Distributed $h_{\infty}$ equalization control for multi-node power generation systems, proceeding of the 11 th world congress on intelligent control and automation," 2014.

[53] J. Fischer, S. González, I. Carugati, M. Judewicz, and D. Carrica, "Control directo de potencia predictivo robusto con sincronismo intrínseco," Revista Iberoamericana de Automática e Informática industrial, vol. 12, p. 199-207, 2015.

[54] Y. A.-R. I. Mohamed, H. H. Zeineldin, M. Salama, and R. Seethapathy, "Seamless formation and robust control of distributed generation microgrids via direct voltage control and optimized dynamic power sharing," IEEE Transactions on Power Electronics, vol. 27, no. 3, p. 1283-1294, 2012.

[55] M. Mehrasa, E. Pouresmaeil, and J. P. Catalão, "Direct lyapunov control technique for the stable operation of multilevel converter-based distributed generation in power grid," IEEE Journal of Emerging and Selected Topics in Power Electronics, vol. 2, no. 4, p. 931-941, 2014.

[56] Y.-T. Weng and Y.-Y. Hsu, "Sliding mode regulator for maximum power tracking and copper loss minimisation of a doubly fed induction generator," IET Renewable Power Generation, vol. 9, no. 4, pp. 297-305, 2015. 
[57] J. Chai and R. G. Sanfelice, "A robust hybrid control algorithm for a single-phase dc/ac inverter with variable input voltage," American Control Conference (ACC, p. 1420-1425, 2014.

[58] V. Yaramasu, M. Rivera, M. Narimani, B. Wu, and J. Rodriguez, "High performance operation for a four-leg npc inverter withtwo-sample-ahead predictive control strategy," Electric Power Systems Research, vol. 123, p. 31-39, 2015.

[59] A. J. Real and A. Arce, "Carlos bordons, combined environmental and economic dispatch of smart grids using distributed model predictive control," Electrical Power and Energy Systems, vol. 54, p. 65-76, 2014.

[60] D. Wang and M. Glavic, "Louis wehenkel, comparison of centralized, distributed and hierarchical model predictive control schemes for electromechanical oscillations damping in large-scale power systems," Electrical Power and Energy Systems, vol. 58, p. 32-41, 2014.

[61] M. Shiroei and A. Ranjbar, "Supervisory predictive control of power system load frequency control," Electrical Power and Energy Systems, vol. 61, p. 70-80, 2014.

[62] M. Ma, H. Chen, X. Liu, and F. Allgöwer, "Distributed model predictive load frequency control of multiarea interconnected power system," Electrical Power and Energy Systems, vol. 62, p. 289-298, 2014.

[63] G. Bruni, S. Cordiner, V. Mulone, V. Rocco, and F. Spagnolo, "A study on the energy management in domestic micro-grids based on model predictive control strategies," in Energy Procedia, International Conference on Applied Energy (ICAE), vol. 61, p. 1012-1016, 2014.

[64] P. Kou, F. Gao, and X. Guan, "Stochastic predictive control of battery energy storage for wind farm dispatching: Using probabilistic wind power forecasts," Renewable Energy, vol. 80, p. 286-300, 2015.

[65] Z. Guo, H. Jiang, Y. Zheng, and S. Li, "Distributed model predictive control for efficient operation of islanded microgrid, chinese automation congress (cac)," 2017.

[66] X.-F. Li, J. Sun, H.-Y. Wu, and W.-D. Zong, "Application of the fuzzy-pid to the power plant," in Annual Meeting of the North American Fuzzy Information Processing Society (NAFIPS, p. 210-215, 2007.

[67] R. Garduno-Ramirez and K. Lee, "Fuzzy gain-scheduling pid+decoupling control for power plant widerange operation," in International Conference on Intelligent Systems Applications to Power Systems (ISAP, p. 1-6, 2007.

[68] H. Shayeghi, H. Shayanfar, and A. Jalili, "Multi-stage fuzzy pid power system automatic generation controller in deregulated environments," Energy Conversion and Management, vol. 47, p. 2829-2845, 2006.

[69] Z. Guo and K. Y. Lee, A self-adaptive fuzzy PI controller of power conditioning system for hybrid fuelcell/turbine power plant. North American Power Symposium (NAPS), 2011.

[70] G. S. Rabindra Kumar Sahu and S. Panda, "De optimized fuzzy pid controller with derivative filter for Ifc of multi source power system in deregulated environment," Ain Shams Engineering Journal, vol. 6, p. 511-530, 2015.

[71] R. Patnaik and P. Dash, "Impact of wind farms on disturbance detection and classification indistributed generation using modified adaline network and anadaptive neuro-fuzzy information system," Applied Soft Computing, vol. 30, p. 549-566, 2015.

[72] M. F. Z. Souza, Y. Reis, A. B. Almeida, and I. Lima, "Antonio carlos zambroni de souza, load margin assessment of systems with distributed generation with the help of a neuro-fuzzy method," IET Renewable Power Generation, vol. 9, no. 4, p. 331-339, 2015.

[73] I. Kumarswamy and T. K. Sandipamu, "Venkata prasanth, analysis of islanding detection in distributed generation using fuzzy logic technique," in 7th Asia Modelling Symposium (AMS), p. 3-7, 2013. 
[74] P. Dash and T. Malhar Padhee, "A hybrid time-frequency approach based fuzzy logic system for power island detection in grid connected distributed generation," Electrical Power and Energy Systems, vol. 42, p. 453-464, 2012.

[75] H. Shayeghi and B. Sobhani, "Zero ndz assessment for anti-islanding protection using wavelet analysis and neuro-fuzzy system in inverter based distributed generation," Energy Conversion and Management, vol. 79, p. 616-625, 2014.

[76] A. Wang, "Design of fuzzy power system for distributed generation system," in 2nd International Conference on Intelligent Control and Information Processing (ICICIP), vol. 2, p. 881-884, 2011.

[77] A. Wang, "Optimization of fuzzy power system for distributed generation system using genetic algorithm," in International Conference on Computer Distributed Control and Intelligent Environmental Monitoring (CDCIEM), p. 537-540, 2011.

[78] S. Chakraborty and M. G. Simões, "Fuzzy artmap based forecast of renewable generation for a high frequency ac microgrid," in 31st Annual Conference of IEEE Industrial Electronics Society (IECON, 2005.

[79] H. Yousef, "Adaptive fuzzy logic load frequency control of multi-area power system," Electrical Power and Energy Systems, vol. 68, p. 384-395, 2015.

[80] H. Weiss and J. Xiao, "Fuzzy system control for combined wind and solar power distributed generation unit," IEEE International Conference on Industrial Technology, vol. 2, p. 1160-1165, 2003.

[81] T. Kumar, N. Subrahmanyam, and M. Sydulu, "Control strategies of a fuzzy controlled solid oxide fuel cell/battery distributed generation system for power quality enhancement," in International Conference on Circuit, Power and Computing Technologies (ICCPCT), p. 64-69, 2014.

[82] T. Kumar, Y. Chandrashekar, N. Subrahmanyam, and M. Sydulu, "Control strategies of a fuzzy controlled grid connected hybrid pv/pemfc/battery distributed generation system," in IEEE Power and Energy Conference at Illinois (PECI), 2015.

[83] I. Pan, Saptarshi Das, Fractional order fuzzy control of hybrid power system with renewable generation using chaotic PSO. ISATransactions, 2015.

[84] T. V. Mukherjee, "A novel quasi-oppositional harmony search algorithm and fuzzy logic controller for frequency stabilization of an isolated hybrid power system," Electrical Power and Energy Systems, vol. 66, p. 247-261, 2015.

[85] I. Mado, A. Soeprijanto, and Suhartono, "Design of robust-fuzzy controller for smib based on power-load cluster model with time series analysis, electrical power, electronics," in Communications, Controls and Informatics Seminar (EECCIS), p. 8-15, 2014.

[86] S. Seyedalipour, H. A. Aalami, and A. Barzegar, "A lyapunov function-based adaptive fuzzy control for integration of distributed generation resources to electrical networks," in 5th Iranian Joint Congress on Fuzzy and Intelligent Systems (CFIS), p. 184-189, 2017.

[87] A. Hajizadeh and M. A. Golkar, "Intelligent power management strategy of hybrid distributed generation system," Electrical Power and Energy Systems, vol. 29, p. 783-795, 2007.

[88] A. Hajizadeh and M. Golkar, "Fuzzy neural control of a hybrid fuel cell/battery distributed power generation system," IET Renewable Power Generation, vol. 3, no. 4, p. 402-414, 2009.

[89] S. K. Nayak, D. Gaonkar, and R. Shivarudraswamy, "Fuzzy logic controlled microturbine generation system for distributed generation," in 2nd International Conference on Advances in Energy Engineering (ICAEE2011), Energy Procedia, vol. 14, p. 1213-1219, 2011. 
[90] A. R. Sakhare, A. Davan, and A. Feliachi, "Control of stand alone solid oxide fuel cell using fuzzy logic," in Proceedings of the 35th Southeastern Symposium on System Theory, p. 473-476, 2003.

[91] D. Pan and F. Wang, "Modeling and simulation of fuzzy control system for dual stator winding induction generator," in Proceeding of International Conference on Electrical Machines and Systems, 2007. 